\title{
Socioeconomic Analysis on Problems and Prospects of Major Pulse Productions and Consumption in Bihar, India
}

\author{
Meera Kumari ${ }^{1}$, M. Bhattarai ${ }^{2}$, *L.K. Meena ${ }^{1}$, S.L. Bairwa ${ }^{1}$, \\ Sk. M. Rahaman ${ }^{1}$ and S. Kumar ${ }^{1}$ \\ ${ }^{1}$ Department of Agricultural Economics, Bihar Agricultural University, \\ Sabour, Bhagalpur-813210, India \\ ${ }^{2}$ Scientist ICRISAT, Patancheru, Hyderabad, India \\ *Corresponding author
}

\section{A B S T R A C T}

\begin{tabular}{|l|}
\hline K e y w o r d s \\
Consumption \\
expenditure, \\
cost-benefit \\
analysis, \\
pulses, Bihar.
\end{tabular}

Keywords

Consumption expenditure, cost-benefit analysis,

\section{Introduction}

Pulses in India have long been considered as the poor man's only source of protein. Pulses are grown on 23 million hectares of area with an annual production of 15 million tons in 2003-04, it has been increased to 25 million hectare in the year 2013-14 and production during the same has been increased from 15 to19.7 million tones. However productivity has been increased from $635 \mathrm{Kg} / \mathrm{ha}$ to $785 \mathrm{Kg} / \mathrm{ha}$ over the period. Due to stagnant production, the net availability of pulses has come down from $60 \mathrm{gm} /$ day/person in 1951 to 
$31 \mathrm{gm} /$ day/person (Indian Council of Medical Research recommends $65 \mathrm{gm} /$ day/capita) in 2008. The requirement of pulses will continue to increase in future mainly due to ever increasing population and preference for pulses as the cheapest source of dietary protein. Our prime Minister call for second green revolution of the country with emphasis on enhancement of pulse production to ensure food and nutritional security of people also finds the Bihar is most suitable for it. The central Agriculture Ministry has also identified gaps in the present strategy to increase production of pulses and also identified lack of availability of new varieties of seeds as an important hindrance in increasing productivity of pulses.

In Bihar Agriculture sector has experienced a considerable growth during the past three decades. The progress has been spectacular in 1980's when state recorded agriculture growth of 2.50 percentages which outpaced the population growth $(2.35 \%)$ during the period which could not be sustained during nineties (AICRPs, 2011). In the process of technological development in Bihar, pulse crops got major setback and its area declined from6913 thousand hectares in 2003-04 to 500thousand hectare in the year 2013-14. It produces 562.6thousand tones of pulses in 2003-04, which has been declined to522 thousand tones during2013-14 (Govt. of Bihar 2014).This is only $4 \%$ of pulse production of the country. However productivity of pulses has been increased from $814 \mathrm{Kg} / \mathrm{ha}$ to 1044 $\mathrm{Kg} / \mathrm{ha}$ during the same period, which is higher than the national average. Definitely, there is ample scope for enhancing the productivity of the individual pulses in the state. However emphasis will be given on an increase in area of pulses bedside adoption of improved production and protection practices (Kumari et al., 2016). The percentage area under pulses to gross cropped area has also been declined with an increase in gross irrigated area (Chopra, 1982). Among pulse crop grown in Bihar Lentil is the only pulse crop whose cropped area increased by 20,000 hectares. Its production is still greater to all India average $(991 \mathrm{~kg} / \mathrm{ha})$. Particular reference to major pulses like chickpea and pigeon pea in Bihar, the area and production of both the pulses has been declined, due to growing popularity and public policy emphasis on Rice-Wheat system (Anonymous, 2012). It has been noted that the area under pigeon pea declined over the year by 35 percent and that of chickpea and lathyrus each by about 60 percent (compiled from data). It was estimated about 22 thousand hectare area of pigeon pea and 42 thousand metric tons production in 20012-13 and its productivity was about $1901 \mathrm{Kg} / \mathrm{ha}$ DES, 2015).

It has been noticed that as irrigation facilities developed, chickpea gradually gets marginalized in Bihar and other parts of IndoGenetic Plains (Ranjan, et al., 1996). In addition to this, there is a huge variability in area and production of major pulses during 2000-2009, however the productivity during the same period is more stable which indicates that there is a scope to increase production potential of major pulses in the state if adequate policy measures are taken (Kumari et al., 2015). In this regard it is pertinent to take into account the one million ha of rice fallow land in the state to which the chickpea and other pulses cultivation could be potentially expanded (F.A.O, 2009). To identify the problem and opportunity, this paper has been planned with main aimed at increasing the area and production of chickpea through intervention of improved varieties along with management practices in target districts of Bihar.

\section{Materials and Methods}

The study was mainly based on collection of primary data. The target districts were 
selected for conducting baseline survey on major pulse cultivation (chickpea and pigeon pea cultivation) in Bihar were Banka and Bhagalpur for the period of 2011-12 under collaborative project of TL-2. In each district a cluster of 3 villages from two different blocks were selected as adopted village and 3 villages from surrounding areas with comparable agro ecological and market condition were chosen to serve as control villages. In total, 6 villages in each district were identified for the same. Stratified Random Sampling technique based on probability proportion to size method to farm size was used to conduct the interview. From each of the adopted villages a sample of 30 farmers \&from each of the control villages a sample of 15 farmers were interviewed. Thus, a total of 135 from each district totaling to 270 farmers were interviewed to assess the socio -economic profiles, constraints faced, income and liability of farmer for cultivation of two major pulses in Bihar.

\section{Analytical technique}

For assessing the trends in area, production and productivity of major pulses in the states and the study districts of Bhagalpur and Banka, the exponential function of $Y_{T}=a b^{t} u^{t}$ was employed. Where, $\mathrm{Y}_{\mathrm{T}}=$ area/production/productivity in the year's' a = intercept indicating $\mathrm{Y}$ in the base period $(\mathrm{t}=$ $0), b=$ Regression coefficient, $t=$ Time period in years

$\mathrm{U}_{\mathrm{t}}=$ Disturbance term for the year's'.

\section{Garrett's ranking techniques}

It was used for constraints analysis, in analysis, rank 1 means most important problem and rank 10 means least important problem. In the next stage rank assigned to each reason by each individual was converted into per cent position by using the formula:
Per cent position $=100\left(\mathrm{R}_{\mathrm{ij}}-0.5\right) / \mathrm{N}_{\mathrm{J}}$

Where, $R_{i j}$ stands for rank given for the $I^{t}$ factor $(i=1,2 \ldots .5)$ by the $j_{t h}$ individual $(j=1$, $2 \ldots \ldots, n$ ) $\mathrm{N}_{\mathrm{j}}$ stands for number of factors ranked by $\mathrm{j}^{\text {th }}$ individual. Once the per cent positions were found, scores were determined for each per cent position by referring Garrett's table. Then, the scores for each problem were summed over the number of respondents who ranked that factor. In this way, total scores were arrived at for each of the factors and mean scores were calculated by dividing the total score by the number of respondents who gave ranks. Final overall ranking of the factors was carried out by assigning rank 1, 2, 3... etc., in the descending order of the mean scores.

\section{Major findings}

The area under major pulse crops over the decade indicated that there was steep decline in area under pigeon pea and chickpea. However productivity of these pulses increased consistently (Kumari et al., 2015).

\section{Status and importance of major pulses in sample districts of Bihar}

Relative importance of pulses in the districts as a whole was 20 percent of gross cropped area. Among pulses chickpea accounts 60 percent of area to total pulse area in the districts. In Bhagalpur, the average area under chickpea in triennium ending 2000 was 5042 hectare producing 4416 tons with productivity of $872 \mathrm{~kg}$ per hectare. Chickpea is also one of the major pulse crops in Banka district with an area of 3873ha during 2000 after that it has declined to 2477ha till 2009 triennium ending however average production has been stagnated over the period. But productivity level raised from $716 \mathrm{~kg} / \mathrm{ha}$ to $1057 \mathrm{~kg} / \mathrm{ha}$. This requires the suitable policy to develop the technology of processing, storage and 
sustainable production for the livelihood security of people in Bihar.

\section{Place of pigeon pea in cropping pattern and productivity level}

The other major pulses were pigeon pea, constituted about 12 to $13 \%$ in the rainy season cropped area. The percentage of area under pigeon pea was higher $(13.31 \%)$ in Bhagalpur than that of Banka $(8.63 \%)$. It clearly reveals that pulses were neglected crop in the study districts and farmers have excessive dependence on a single crop in rainy season that is Rice. The main reasons expressed by the respondents for the cultivation of rice were that, it is stable crop fetches higher yield and is best suited to their marginal lands. In spite of the fact that pigeon pea requires low-input and restores the soil fertility farmers were reluctant to cultivate rice only in rainy season. Other competing crop was maize, which was also more remunerative crop than pigeon pea. That is why majority of area under pigeon pea in Banka were on Bund, despite of fetching higher income without using any fertilizer and other nutrient for their growth (Table 1).

\section{Place of chickpea in cropping pattern and productivity level}

However the relative importance of chickpea crop to total cropped area (Kharif, Rabi and summer) was accounted nearly about 20 to 36 percent in control and adopted Village respectively. Size group analysis revealed that the pulse crops were given more importance by the large farmers followed by small and marginal farmers, due to the fact that pulse crop being less capital intensive may be cultivated extensively to cover all the land under cultivation particularly by the large farmers.

From the observation of cropping pattern of sample districts it may be inferred that district
Bhagalpur occupied more area under chickpea in Rabi followed by kharif crop across each size group of farms. It clearly indicates that pulse crops were not given equal importance as given to the wheat, maize and paddy by the farmer of selected districts (Table 2).

\section{Productivity of chickpea in selected district of Bihar}

Varieties -wise productivity analysis indicated that, average productivity of improved varieties did better in Banka(1042.34kg/ha).Among all varitiesJG14 proved superior over kak-2 $(832.74 \mathrm{~kg} / \mathrm{ha})$ in particular location but it was observed that they were reaping only half of potential yield due to postharvest losses, germination problems, high disease infestation etc.

Average yield of chickpea in Banka was comparatively higher than that of Bhagalpur, as shown in table 2. Among improved variety given to the farmer JG-14(1000kg/ha) gives better yield in Banka followed by RADHA $(1010.45 \mathrm{~kg} / \mathrm{ha})$ and $\mathrm{KAK}-2$ and it was also reported as most preferred variety among improved cultivar. On the basis of above observation i.e. comparative yield analysis of both district it may concluded that, farmers of both districts were still relying on traditional varieties due to risk associated with improved varieties, more occurrence of disease and pest, Germination problems of KAK2 in few villages like Rajpur.

Postharvest losses in KAK2 were also higher due to rat attack on farmer field. For Better impact some initiative like large number of farmer should have been identified for distribution of seed, early sown variety should be given to the farmers of flood affected area, and late sown variety should be promoted in rice-wheat dominated areas of all villages selected under study to regain the area under pulses in Bihar (Table 3). 


\section{Productivity of pigeon pea in selected districts of Bihar}

Productivity level of 'local variety like Deshla/Tikariya, gives comparatively higher yield in adopted village of Bhagalpur $(1334 \mathrm{~kg} / \mathrm{ha}))$. Among varieties distributed to the farmers ICPH 2671, ICPH 7035 and Asha were most acceptable variety in both the districts. The major problems associated with these were germination\& non-suitability into cropping pattern. The productivity level of improved variety ranged in between $1100-$ $1400 \mathrm{~kg} / \mathrm{ha}$ in selected districts of the Bihar state. In Local varieties, Tikaria was observed as a single variety in both of districts selected for survey. Variety ICPH 7035 was most suitable variety among improved varieties (Table 4).

\section{Economic analysis of chickpea cultivation}

Economic analysis of growing different crops is very important to understand which crop is most remunerative in terms of getting higher return on investment. The cost of cultivation, input output ratio associated with growing chickpea has been presented in table 5 .

Comparative economics of chickpea indicated that BCR of improved variety was comparatively more than that of local variety. Despite of these fact farmers still prefers local variety to grow pulses. For better impact awareness program as well as proper package of practices should be made available to them easily. Proportion of expenditure on human labor was found highest on harvesting and threshing (Rs 5532.33) followed by material input like seed cost (Rs 3286) in adopted and control village (4554.01 and 2645) respectively out of total cost Rs 15392 /ha and14352 spent on cultivation of chickpea under study. However the cost of cultivation of improved varieties was varies between Rs 18200-19280/ha, which was comparatively higher than local variety. It was mainly due to fact that while using local variety farmer were using own seed and due to higher prices of improved seed and proper package of practices used by the famer while cultivating improved varieties. The estimated net returns wasRs13438 to14368 /ha in sample village for local varieties and Rs17480- 19520 for improved varieties under studies. It clearly indicated the comparative advantage of chick pea than other competing crop like wheat (compiled other crop also). Comparative cost and benefit analysis indicated that pulses crop are more remunerative crop for Banka than Bhagalpur (1.6) as benefit cost ratio for local verities were higher (1.9) in Banka. But for improved verities it was estimated higher in Bhagalpur (2.01). It means improved variety given to farmer were found more suitable in Bhagalpur districts. Results supported by the findings of Meena et al., (2014).

However for pigeon pea, BCR of local variety in Banka district (4.0) was comparatively more than that of Bhagalpur (3.0). The difference between input-output ratio of local and improved variety was only due to difference in the harvest price of improved variety (limited availability of that variety among the farmers), otherwise cost involved in different operation was also more or less similar i.e. ranged from Rs. 12428.97 to Rs. 18082.50 in respective districts. Thus, it is obvious that input-output ratio for improved variety was found similar to local variety\& net income per hectare worked out was found highest for improved variety followed by local variety in sample villages under study. These results are quite similar as AICRP (2011). One of the important point noted that despite of better comparative advantage of this crop farmer were not interested to allocate the main land for pigeon pea they usually prefer to grow in bund. These results are similar as obtained by ICAR (2010) and Sahu and Jiyawanv (2012) (Tables 5 and 6). 


\section{Income and expenditure analysis of pulses} in Bihar

The total household income on an average was worked out to be Rs.250782 for adopted villages of Bhagalpur which was found to be highest followed by adopted village of Banka district (Rs.169839). Among control villages it was comparatively higher for Banka district than that of Bhagalpur and was estimated to be Rs.130629 and Rs.113407 respectively. Regular salaried Job figured to be the major source of income in both the districts i.e. contribution of non-farm income was estimated about 82061 for adopted villages of Bhagalpur and Rs.82167/Year for adopted villages of Banka. Earning from business figured out to be the third most important source of income and accounted for about Rs.2277 out of Rs. 130629 followed (Rs.12222) and (Rs.9967) respectively by adopted and control villages of Bhagalpur. It was further revealed that contribution of income to the total income from crop was Rs70983.5in adopted village which was accounted next to salaried job i.e. placed second and in control village it was estimated only Rs 26905.5, despite of the fact that majority of part of population of selected districts i.e. $53 \%$ of total population mainly depend upon agriculture followed by business and services (Table 7).

The annual household consumption expenditure pattern of sample farmers in Bihar is shown in table 8 since rice is the main staple food for the farmers; it occupied nearly 30 per cent of the share in the total cost on cereal in both control and adopted villages. Among the pulses group the expenditure on chick pea is more than that of pigeon pea because pigeon pea being costly only big farmers have been used for the purpose of consumption. Overall, the average consumption expenditure per household per year is slightly higher in adopted villages when compared with controlled villages. This trend is in contrast to the earlier pattern observed in household income of sample farmers in the adopted and control villages. In both adopted and control villages, the expenditure incurred on pulses was around $15.60 \%$ of total food expenditure. Yet, the expenditure on food and non-food items was higher in sample household in adopted villages when compared with control villages. The food expense was around 60-62\% whereas non-food expense, education was the single largest component which the make Rs 14000in adopted villages which was more than in control villages (Rs11000). One remarkable point had been observed while analysis that consumption expenditure on food item was comparatively more in control villages under study as indicted in table 8 (Rs 49041). Findings support the angel law, higher the income lower the expenditure on food items and vice-versa.

\section{Problem and prospects of major pulse production in Bihar}

Major constraints among cultivar in Bhagalpur for local variety was observed as low yield followed by high pod borer incidence, low market price, having no attractive color and small grain size was ranked $1^{\text {st }}, 2^{\text {nd }} 3^{\text {rd }}, 4^{\text {th }}$ and $5^{\text {th }}$ respectively (Table 9). For improved varieties it was high pod borer incidence followed in not attractive color, High disease incidence, not fitting into cropping system and poor taste were given the $1^{\text {st }} 2^{\text {nd }}, 3^{\text {rd }}, 4^{\text {th }}$ and $5^{\text {th }}$ ranked respectively. In Banka district, the major constrains in order of importance were low yield, high pod borer incidence, high disease incidence, small grain size and low recovery of dal percentage as $1^{\text {st }}$, $2^{\text {nd }}, 3^{\text {rd }}$, and $5^{\text {th }}$ rank respectively for local variety and high pod borer incidence followed by low yield, high disease incidence, long duration\& not fitting into cropping system as $1^{\text {st }}, 2^{\text {nd }}, 3^{\text {rd }}, 4^{\text {th }}$, and $5^{\text {th }}$ respectively for 
improved variety. Thus it may be concluded that major constraints among cultivar was the pest and disease for improved variety and Low yield was the main problem for local varieties of chickpea production in study districts of Bihar.

In conclusion, decline in area of pulses was mainly due to insecure harvest of crop in isolated pockets due to social factor. Among variety targeted for cultivation, JG-14, KAK2 and Subhra were found most acceptable and suitable variety in the farmer's field of both the districts in Bihar for chickpea, however for the pigeon pea ICPH 7035 was most suitable variety among improved varieties. Regarding local variety one of the major setbacks was that it has not been replaced by the farmer from 20 to 25 years. One remarkable point has been observed that consumption expenditure on food item like rice and wheat was comparatively more than pulses (only15percent) despite of having nutritional importance in the dietary pattern. Particularly among the poor people who cannot afford animal products to supplement protein requirement of macro and micro nutrients. Major constraints for pulse production in Bihar are that, the suitable variety is not available in the market; erratic rainfall causes moisture stress, disease and insect infestation etc. To increase area and production of pulses we need region specific approaches which should be adopted in the overall framework of system approach. There is a ample scope for pulses industry also that's why special attention in these areas needs to explore the technology for optimization of pulse production. Because, for diversification pulse crop is one of the reliable option with new technology interventions (improved seed, package and practice) to regain some area in the state as whole and districts in particular.

Table.1 Relative importance of pigeon pea crop in cropped area of Bihar sample, 2011-12

\begin{tabular}{|l|l|l|l|l|l|l|}
\hline \multirow{2}{*}{ Cropped area } & \multicolumn{2}{l|}{ Bhagalpur } & \multicolumn{2}{l|}{ Banka } & \multicolumn{2}{l|}{ Pooled Sample } \\
\cline { 2 - 7 } & Adopted & Control & Adopted & Control & Adopted & Control \\
\hline $\begin{array}{l}\text { Rainy season cropped area } \\
\text { (ac) }\end{array}$ & $\mathbf{4 2 2 . 5 0}$ & $\mathbf{1 8 8 . 5 0}$ & $\mathbf{2 7 5 . 4 4}$ & $\mathbf{6 2 . 2 3}$ & $\mathbf{6 9 7 . 9 4}$ & $\mathbf{2 5 0 . 7 3}$ \\
\hline $\begin{array}{l}\text { Post rainy season cropped } \\
\text { area (ac) }\end{array}$ & $\mathbf{4 1 9 . 0 0}$ & $\mathbf{3 2 0 . 5 0}$ & $\mathbf{3 1 7 . 0 0}$ & $\mathbf{5 0 . 7 5}$ & $\mathbf{7 3 6 . 0 0}$ & $\mathbf{3 7 1 . 2 5}$ \\
\hline Area under Pigeon pea (ac) & 117.00 & 64.50 & 51.15 & 12.48 & 168.15 & 76.98 \\
\hline $\begin{array}{l}\text { Proportion of Pigeon pea } \\
\text { area to total }\end{array}$ & $13.31 \%$ & $12.46 \%$ & $8.63 \%$ & $11.05 \%$ & $11.43 \%$ & $12.21 \%$ \\
\hline
\end{tabular}

Table.2 Relative importance of chickpea crop in cropped area of Bihar sample, 2011-12

\begin{tabular}{|l|c|c|c|c|c|c|}
\hline \multirow{2}{*}{ Cropped area } & \multicolumn{2}{|l|}{ BHAGALPUR } & \multicolumn{2}{l|}{ BANKA } & \multicolumn{2}{l|}{ Pooled Sample } \\
\cline { 2 - 7 } & $\mathrm{A}$ & $\mathrm{C}$ & $\mathrm{A}$ & $\mathrm{C}$ & $\mathrm{A}$ & $\mathrm{C}$ \\
\hline Rainy season cropped area (ha) & 55.66 & 16.39 & 73.53 & 32.18 & 129.19 & 48.58 \\
\hline Post rainy season cropped area (ha) & 321.40 & 20.14 & 82.94 & 36.84 & 404.35 & 56.98 \\
\hline $\begin{array}{l}\text { Area under post- rainy season } \\
\text { chickpea area post rainy area (ha) }\end{array}$ & 60.17 & 16.49 & 45.90 & 21.96 & 106.07 & 38.46 \\
\hline $\begin{array}{l}\text { Proportion of chickpea area to total } \\
\text { cropped area (\%) }\end{array}$ & $16 \%$ & $45 \%$ & $29 \%$ & $32 \%$ & $20 \%$ & $36 \%$ \\
\hline
\end{tabular}

(Source: compiled by the Authors) 
Table.3 Productivity of chickpea by varieties in Bihar sample, 2011-12 ( $\mathrm{kg} / \mathrm{ha})$

\begin{tabular}{|l|c|c|c|c|c|c|}
\hline & \multicolumn{2}{|c|}{ BHAGALPUR } & \multicolumn{2}{c|}{ BANKA } & \multicolumn{2}{c|}{ Pooled Sample } \\
\cline { 2 - 7 } & Adopted & Control & Adopted & Control & Adopted & Control \\
\hline DESHLA ROON & 732.77 & 741.00 & 946.83 & 900.35 & 848.03 & 890.70 \\
\hline DESLA PLAIN & 668.66 & 626.32 & 776.09 & 638.08 & 702.53 & 627.11 \\
\hline JG-14 & 790.40 & 0 & 1042.34 & 0 & 1000.35 & 0 \\
\hline KAK-2 & 988.00 & 0 & 806.87 & 0 & 832.74 & 0 \\
\hline RADHA & 864.50 & 494.00 & 0 & 671.84 & 1010.45 & 630.80 \\
\hline SUBHARA & 839.80 & 0 & 0 & 370.50 & 790.40 & 370.50 \\
\hline VAIBHAV & 699.83 & 0 & 0 & 0 & 699.83 & 0 \\
\hline
\end{tabular}

(Source: compiled by the Authors)

Table.4 Variety wise productivity of pigeon pea in selected districts of Bihar $(\mathrm{kg} / \mathrm{ha})$

\begin{tabular}{|l|c|c|c|c|c|c|}
\hline \multirow{2}{*}{ Varieties } & \multicolumn{2}{|c|}{ Banka } & \multicolumn{2}{c|}{ Bhagalpur } & \multicolumn{2}{c|}{ Pooled } \\
\cline { 2 - 7 } & Adopted & Control & Adopted & Control & Adopted & Control \\
\hline Pusha-9 & 0 & 0 & 1363 & 1375 & 681.5 & 687.5 \\
\hline Tikariya & 1027 & 300 & 1334 & 1172 & 1180.5 & 736 \\
\hline Local/Maghauya & 929 & 0 & 1350 & 1236 & 1139.5 & 618 \\
\hline Asha & 984 & 0 & 1363 & 1333 & 1173.5 & 666.5 \\
\hline ICPH-2671 & 1147 & 0 & 1400 & 0 & 1273.5 & 0 \\
\hline ICPH-2678 & 0 & 0 & 1250 & 0 & 625 & 0 \\
\hline ICPH-2740 & 937 & 0 & 1260 & 0 & 1098.5 & 0 \\
\hline ICPH-3762 & 1109 & 0 & 1415 & 0 & 1262 & 0 \\
\hline ICPH-7035 & 750 & 0 & 1140 & 0 & 945 & 0 \\
\hline
\end{tabular}

Source: Field survey, 2011-12

Table.5 Gross returns and cost incurred from different verities of chickpea grown by sample farmers in Bihar 2011-12 (Rs.'000/ha)

\begin{tabular}{|l|c|c|c|c|}
\hline \multirow{2}{*}{} & \multicolumn{2}{|c|}{ BHAGALPUR (Rs per ha) } & \multicolumn{2}{c|}{ BANKA (Rs per ha) } \\
\cline { 2 - 5 } & Adopted & Control & Adopted & Control \\
\hline Rain fed /Local DESHLA PLAIN (LOCAL) DESHLA RUN(LOCAL) & \\
\hline Yield (kg/ha) & 708 & 616 & 794 & 839 \\
\hline COC(Rs/ha) & 15392 & 11942 & 14352 & 14997 \\
\hline Gross returns(Rs/ha) & 24780 & 21560 & 27790 & 29365 \\
\hline Net returns (Rs/ha) & 9388 & 9618 & 13438 & 14368 \\
\hline BCR & 1.6 & 1.8 & 1.9 & 1.95 \\
\hline Irrigated/Improved IMPROVED KAK-2(IMPROVED) & 0 \\
\hline Yield (kg/ha) & 970 & 0 & 892 & 0 \\
\hline COC (Rs/ha) & 19280 & 0 & 18200 & 0 \\
\hline Gross returns (Rs/ha) & 38800 & 0 & 35680 & 0 \\
\hline Net returns (Rs/ha) & 19520 & 0 & 17480 & 0 \\
\hline BCR & 2.01 & 0 & 1.96 & \\
\hline
\end{tabular}

(Source: compiled by the Authors) 
Table.6 Economics of local and improved cultivars of pigeon pea in selected districts in Bihar

\begin{tabular}{|l|c|c|c|c|}
\hline \multirow{2}{*}{} & Bhagalpur (Rs Per Ha) & \multicolumn{2}{c|}{ Banka (Rs Per Ha) } \\
\cline { 2 - 5 } & Adopted & Control & Adopted & Control \\
\hline Local cultivars & 1141.48 & 1024.76 & 1100.13 & 1178.19 \\
\hline Yield (kg/ha) & 18082.50 & 17892.90 & 11536.70 & 12428.97 \\
\hline COC(Rs/ha) & 52446.52 & 48016.21 & 50154.66 & 43609.81 \\
\hline Gross returns(Rs/ha) & 34364 & 30123 & 38617.96 & 35037.32 \\
\hline Net returns (Rs/ha) & 3.0 & 3.0 & 4.0 & 4.0 \\
\hline BCR & 1452.75 & & 1472.12 & - \\
\hline Improved cultivars & 18082.50 & & 12428.97 & - \\
\hline Yield (kg/ha) & 57468.94 & & 46376.38 & - \\
\hline COC (Rs/ha) & 39386.44 & & 33947.41 & - \\
\hline Gross returns (Rs/ha) & 3.0 & & 4.0 & \\
\hline Net returns (Rs/ha) & & & \\
\hline BCR &
\end{tabular}

Source: Field survey, 2011-12

Table.7 Net household income of sample farmers, in 2011-12 (Rs/Year)

\begin{tabular}{|c|c|c|c|c|c|c|}
\hline \multirow[t]{2}{*}{ Source of income } & \multicolumn{2}{|c|}{ BHAGALPUR } & \multicolumn{2}{|l|}{ BANKA } & \multicolumn{2}{|l|}{ Pooled } \\
\hline & Adopted & Control & Adopted & Control & Adopted & Control \\
\hline Income from crops & 92717 & 27544 & 49250 & 26267 & 70983.5 & 26905.5 \\
\hline Farm work (labor earnings) & 28367 & 11156 & 15744 & 12311 & 22055.5 & 11733.5 \\
\hline $\begin{array}{l}\text { Non-farm work (labor } \\
\text { earnings) }\end{array}$ & 11222 & 7089 & 7000 & 7667 & 9111 & 7378 \\
\hline Regular Farm Servant (RFS) & 622 & 1556 & 0 & 444 & 311 & 1000 \\
\hline $\begin{array}{l}\text { Livestock (milk and milk } \\
\text { products selling) }\end{array}$ & 3611 & 2844 & 611 & 21111 & 2111 & 2477.5 \\
\hline $\begin{array}{l}\text { Income from hiring out } \\
\text { bullocks }\end{array}$ & 0 & 222 & 0 & 0 & 0 & 111 \\
\hline Income from livestock selling & 1172 & 729 & 378 & 4356 & 775 & 2542.5 \\
\hline $\begin{array}{l}\text { Selling of water for agriculture } \\
\text { purpose }\end{array}$ & 0 & 0 & 0 & 67 & 0 & 33.5 \\
\hline Rental income & 2444 & 133 & 1600 & 0 & 2022 & 66.5 \\
\hline Business (specify) & 12222 & 9667 & 5667 & 23295 & 8944.5 & 16481 \\
\hline $\begin{array}{l}\text { Regular salaried jobs } \\
\text { (Govt./private) }\end{array}$ & 82061 & 39956 & 82167 & 35111 & 82114 & 37533.5 \\
\hline Out migration & 6111 & 5000 & 0 & 0 & 3055.5 & 2500 \\
\hline Pension from employer & 10233 & 7511 & 7422 & 0 & 8827.5 & 3755.5 \\
\hline Grand Total & 2,50782 & 1,13407 & 1,69839 & 1,30629 & $2,10310.5$ & 1,12518 \\
\hline
\end{tabular}

(Source: compiled by the Authors) 
Table.8 Consumption expenditure of sample farmers, 2011-12 (Rs/Year)

\begin{tabular}{|l|l|l|l|l|l|l|}
\hline \multirow{2}{*}{ Food item } & \multicolumn{2}{|c|}{ Banka } & \multicolumn{2}{c|}{ Bhagalpur } & \multicolumn{2}{c|}{ Pooled } \\
\cline { 2 - 7 } & Adopted & Control & Adopted & Control & Adopted & Control \\
\hline Cereals & 16290 & 17913 & 12208 & 11465 & 14249 & 14689 \\
\hline Pulses & 9757 & 9363 & 5173 & 5530 & 7465 & 7446.5 \\
\hline Milk and Milk products & 11660 & 11280 & 13270 & 14817 & 12465 & 13048.5 \\
\hline Edible oils & 3214 & 3206 & 2666 & 2804 & 2940 & 3005 \\
\hline Non-Veg. Foods & 4539 & 4388 & 4597 & 4716 & 4568 & 4552 \\
\hline Fruits and vegetables & 4757 & 5388 & 5467 & 5224 & 5112 & 5306 \\
\hline Others & 1068 & 902 & 997 & 1086 & 1032.5 & 994 \\
\hline Total food expenditure & $\mathbf{5 1 2 8 5}$ & $\mathbf{5 2 4 4 0}$ & $\mathbf{4 4 3 7 8}$ & $\mathbf{4 5 6 4 2}$ & $\mathbf{4 7 8 3 1 . 5}$ & $\mathbf{4 9 0 4 1}$ \\
\hline Health & 5955 & 4261 & 7544 & 7355 & 6749.5 & 5808 \\
\hline Education & 18298 & 11291 & 11447 & 11663 & 14872.5 & 11477 \\
\hline Entertainment and travel & 1651 & 944 & 1871 & 1568 & 1761 & 1256 \\
\hline Clothing and shoes & 6702 & 6571 & 9075 & 11888 & 7888.5 & 9229.5 \\
\hline Ceremonies & 2250 & 0 & 3791 & 5000 & 3020.5 & 2500 \\
\hline Alcohol and Cigarettes & 945 & 658 & 1177 & 1343 & 1061 & 1000.5 \\
\hline Cosmetics & 2064 & 1586 & 1907 & 1826 & 1985.5 & 1706 \\
\hline Others & 1920 & 1693 & 5724 & 5422 & 3822 & 3557.5 \\
\hline Total Non-food & $\mathbf{3 9 7 8 5}$ & $\mathbf{2 7 0 0 4}$ & $\mathbf{4 2 5 3 6}$ & $\mathbf{4 6 0 6 5}$ & $\mathbf{4 1 1 6 0 . 5}$ & $\mathbf{3 6 5 3 4 . 5}$ \\
\hline Total expenditure & $\mathbf{9 1 0 7 0}$ & $\mathbf{7 9 4 4 4}$ & $\mathbf{8 6 9 1 4}$ & $\mathbf{9 1 7 0 7}$ & $\mathbf{8 8 9 9 2}$ & $\mathbf{8 5 5 7 5 . 5}$ \\
\hline
\end{tabular}

Source: Field survey, 2011-12

Table.9 Major constraints among cultivars (Wt. Scale)

\begin{tabular}{|l|c|c|c|c|}
\hline \multirow{2}{*}{ CONSTRAINTS } & \multicolumn{2}{|c|}{ BHAGALPUR } & \multicolumn{2}{c|}{ BANKA } \\
\cline { 2 - 5 } & Local(d.p) & Local(d.r) & Local & Improved \\
\hline Low yield & $1^{\text {st }}$ & & $1^{\text {st }}$ & $2^{\text {nd }}$ \\
\hline High pod borer incidence & $2^{\text {nd }}$ & $1^{\text {st }}$ & $2^{\text {nd }}$ & $1^{\text {st }}$ \\
\hline High disease incidence & & $3^{\text {rd }}$ & $3^{\text {rd }}$ & $3^{\text {rd }}$ \\
\hline Long duration & & & & $4^{\text {th }}$ \\
\hline Small grain size & $5^{\text {th }}$ & & $4^{\text {th }}$ & \\
\hline Not attractive colour & $4^{\text {th }}$ & $2^{\text {nd }}$ & & \\
\hline Poor taste & & $5^{\text {th }}$ & & \\
\hline Low market price & 3 th & & & \\
\hline Not fit into cropping system & & $4^{\text {th }}$ & $5^{\text {th }}$ & \\
\hline Susceptible to storage pest & & & & $5^{\text {th }}$ \\
\hline
\end{tabular}

(Source: compiled by the Authors)

\section{Implications and Recommendations}

The policy recommendations emerged out from the paper are those; farmer should replace their own seed with improved varieties for getting higher productivity. Secondly for getting higher prices there is a need to improve market information system and for diversification chickpea in rabi and pigeon pea in kharif is one of the reliable 
options with new technology interventions (improved seed, package and practice) to regain some area in the state as whole and districts in particular, the co-ordination of research extension and farmers to encourage farmer's participatory research would be need of the day.

For getting better impact Tal and diara land along with large number of beneficiaries should be included while targeting the technology. The major future expansion of area under pulse crops may take place in rice fallows, where there is no other crop to compete (1.2 million ha) however there are limitations on the successful propagation of these crops in this system. Most of the farmers in Bihar are not aware of the potential economic benefits of using these fallows for legume cultivation. In pulses, improved varieties hardly have a yield advantage of 1520 percent over the traditional varieties.

Steps to reduce the temporal and spatial variation, in price of pulses will definitely help in sustaining as well as enhancing the farmers' interest in pulses. Since the last 10 years, the minimum support price (MSP) announced for all pulse crops has been below the market price. For example, the current MSP is below Rs 30 per $\mathrm{kg}$, while the market price is hovering around Rs 100 for pigeon pea. The government has never treated the MSP as an effective tool for increasing pulses production; it is of the opinion that market forces will take care of acreage allocation and production of pulses. High volatility in prices for long periods, low productivity, and stagnation in production technology has acted as disincentives for pulses production.

\section{References}

AICRPs (2011) Annual Report on Gram, Arhar, Moong, Urad, etc. undertaken by Indian institute of pulse research, Kanpur.
Anonymous (2012). Directorate of Economics and Statistics, Ministry of Agriculture and Cooperation Government of India. Chopra, K. (1982) Pulse production in IndiaA state wise Analysis, Indian Journal of Argil. Economics 37 (3): pp 371 380.

Directorate of Economics and Statistics (2011) Government of Bihar. Ministry of Agriculture and Cooperation, Government of India.

Dubey, A. K., Srivastava, J. P. and Sharma, V. K.(2008). Attitude of respondents towards KVK training programmes. Indian Research Journal Extension Education. 8(2/3):78-80

F.A.O. Stat., (2009) Government of India 2000 Expert Committee Report on Pulses, Technology Mission on Oilseeds and Pulses, Department of Agricultural and Cooperation, Ministry of Agriculture, New Delhi.

Government of Bihar (2008), Bihar Economic Survey-2008-09, Ministry of Finance, Patna, March, pp.23.

Government of Bihar (2008), Bihar through Figure, Department of Statistics and Evaluation, Patna

Government of India (2008), Bihar's Agricultural Development: Opportunities and Challenges", A Report of the Special Task Force on Bihar, New Delhi, April, p.16.

Guy M., Paul K., Agnes M., Florence O., Cecile S., Paul A., Jean B., Alain L. R. (2001) Survey of pigeon pea production systems, utilization and marketing in semi-arid lands of Kenya, Biotechnology. Agron. Soc. Environ., 5 (3): 145-153.

Kumari, M and Bairwa, S.L. (2016) Socioeconomic Assessment of pigeon pea Growers in selected districts of Bihar. The Annals of Agri Bio Research. 21 (1): 101-108. 
Kumari, M and Bairwa, S.L. (2016) Trends in pigeon pea Area, production and productivity in India vs. Bihar. The Annals of Biology. 32 (1): 104-109.

Kumari, M and Singh, R.G. (2016) Production and Marketing of pulses in Bihar. International Journal of Agricultural Science and Research (IJASR) International Journal of Agricultural Science and Research (IJASR), 6 (3): 125-136.

Kumari, M., Bairwa, S.L.and Meena, L.K. (2015) Preferred Traits and Economics of Pigeon Pea Cultivation in Selected District of Bihar. Progressive Research $\quad-A n$ International Journal. 10 (4): 323327.

Kumari, M., Meena, L.K. and Bairwa, S.L. (2015) Socio Economic Assessment of Chickpea Growers in Bihar, India. International Journal of Agricultural Science and Research (IJASR) 5 (4): 21-28.

Meena, L.K., Bairwa, S.L., Lakra, K., and Sirohiya, L. (2014). Analysis of the profile on participating and nonparticipating farmers in chickpea production technology. Agricultural Update 9 (1): 31-36.

Ranjan, K. P and Singh, R.K.P. (1998) Cropping Pattern in Backward Agriculture - A Case of North Bihar. Agricultural Situation in India. pp. 69 -72 .

Ranjan, K. P. (1996) Pulse production in North Bihar during Post-green Revolution Period. The Bihar Journal of Agricultural Marketing. 4 (4): pp $407-416$.

Sahu, R.P. and Jiyawan., R. (2012) Comparative Economics of Pigeon pea Cultivation in the Farmers' Fields in Uttrakhand, Journal of Community Mobilization and Sustainable Development, 7 (2): 171-174.

Salam, M. A., Anwer, M. E. and Alam, M. S. (2013) an analysis Agriculture and the economy of Bihar: International Journal of Scientific and Research. 3 (11) pp 1-19.

\section{How to cite this article:}

Meera Kumari, M. Bhattarai, L.K. Meena, S.L. Bairwa, Sk. M. Rahaman and Kumar, S. 2017. Socioeconomic Analysis on Problems and Prospects of Major Pulse Productions and Consumption in Bihar, India. Int.J.Curr.Microbiol.App.Sci. 6(6): 3150-3161. doi: https://doi.org/10.20546/ijcmas.2017.606.371 